American Journal of Applied Sciences 6 (4): 543-550, 2009

ISSN 1546-9239

(C) 2009 Science Publications

\title{
The Effect of adjusting PH on Stretchability and Meltability to White Brined Nabulsi Cheese
}

\author{
${ }^{1}$ Ayman Suliman Mazahreh, ${ }^{2}$ Jihad M. Quasem, \\ ${ }^{3}$ Ali Faleh Al-Shawabkeh and ${ }^{4}$ Ibrahim Abdullah Afaneh \\ ${ }^{1}$ Al-Balqa Applied University, Princes Alia University College, \\ P.O. Box 941941 Amman 11194 Jordan \\ ${ }^{2}$ Al-Balqa Applied University, Zarqa University College, Zarka, Jordan \\ ${ }^{3}$ Department of Basic Sciences, Faculty of Engineering Technology, \\ Al-Balqa Applied University, P.O. Box 15008 Amman 11134 Jordan \\ ${ }^{4}$ Department of Food Processing, Al-Quds University, P.O. Box 20002, Jerusalem, Via Israel
}

\begin{abstract}
Problem statement: Boiled white brined (Nabulsi cheese) is the mostly consumed in Jordan; this cheese should show meltability and high stretchability in order to fit in the production of high quality Kunafa and other popular local sweets and pastries. The most outstanding characteristic of Nabulsi cheese is the long keeping ability (more than one year) without cooling, since it is preserved in concentrated brine (up to 25\%). Approach: This work was based on the hypothesis that it would be possible to imply meltability and stretchability to the cheese by adjusting $\mathrm{pH}$ to the original brine that may specifically act on cross linking bonds of casein. A new apparatus for measuring the actual stretchability was designed and constructed; measurements on different cheeses proved its validity and reliability to measurement stretchability up to $80 \mathrm{~cm}$. Detailed treatments revealed the success of the proposed assumption in inducing meltability and stretchability to cheese processed and preserved according to the traditional methods. Results: The following results were obtained: It is possible to imply a low but acceptable level of stretchability and meltability through adjustment of the $\mathrm{pH}$ in the range of 5.4-5.8 by adding calculated amount of citric acid considering the buffering capacity of the cheese and storing it for few weeks to reach equilibrium. Conclusion: Conformational experiments proved the applicability of the new method on commercial Nabulsi cheese samples. Sensory evaluation revealed the superiority of $\mathrm{pH}$ adjusting treatment specifically at $\mathrm{pH} 5.4$ and 5.8 as well as commercial Mashmouleh cheese that has high meltability and stretchability when used in Kunafa making.
\end{abstract}

Key words: Nabulsi cheese, PH, stretchability and meltability

\section{INTRODUCTION}

One of the most widely produced cheese type in the Mediterranean, South-East European countries and Middle East countries is white brined cheese ${ }^{[15]}$ this type of cheese is highly consumed in the middle East Countries in many ways mostly as a breakfast, snack or as an essential ingredient of some traditional sweets ${ }^{[6]}$. In Jordan, white brined cheese produced by farmers, seasonal producers and dairy industry, the name is related to Nabuls, a city in the West Bank of Jordan, It is produced by renneting raw sheep milk or a blend of sheep and goat milk to which no starter culture is added $^{[10]}$.

During the manufacture and storage of Nabulsi cheese many changes may arise, such as: non-uniform quality related to flavor abnormalities, gassiness and texture problems ${ }^{[22]}$. Since Nabulsi cheese has a semihard texture and salty flavor, it is often consumed after removing a part of its salt by soaking in water. Moreover, it is used after partial or complete desalting in the production of some bakery products and Arabic sweets particularly Kunafa.

It is desirable that Nabulsi cheese shows the ability to melt and stretch in order to fit in the production of a high quality Kunafa. However, these characteristics are not always available, especially in cheese made from high quality milk where spontaneous fermentation is minimal in the milk as well as in the curd before boiling $^{[6]}$.

Different ways are being practiced to improve these characteristics, firstly, using a mixture of cow,

Corresponding Author: Ayman Suliman Mazahreh, Al-Balqa Applied University, Princes Alia University College, P.O. Box 941941 Amman 11194 Jordan 
sheep or goat milk alone, but this method is not reliable. Secondly, keeping the curd which is produced from raw milk at room temperature for a period of time till it becomes somewhat spongy before it is boiled. Actually, this period may allow a spontaneous growth of natural microflora. However, this method is practiced in Braided cheese Mujadalah or Mushalalah cheese but not practical in Nabulsi cheese and very difficult to control.

A third is, storing boiled cheese in its cans for along period (i.e.) aging. This long period may allow substantial microbial growth namely halotolerant and halophytic microorganisms or the cheese may be altered by certain proteolytic enzymes that affect milk proteins. Also this method is neither practical nor reliable ${ }^{[6]}$.

Although, the way of curd fermentation is the most effective one, it is not controllable and may produce low quality cheese which suffers from excessive deformation, off-color and off-flavor during boiling.

The idea of making cheese stretchable and meltable is to hydrolyze some of the peptide bonds of the more or lees intact proteins (casein) or to destruct some covalent cross-linking bonds of the protein matrix, this can be accomplished through $\mathrm{PH}$ changes (either by direct acidification or through acid production by selected bacterial starter cultures or both), using protease enzymes, particularly coagulation enzymes and emulsifier salts (melting salts) ${ }^{[9]}$.

Investigation on Mozzarella cheese shows that the optimum stretchability is obtained at $\mathrm{PH}$ 5.2-5.4 for biologically acidified cheese or 5.6 for chemically acidified curd. Coagulation enzymes in cheese making have a dual role. The primary function is to coagulation milk in order to produce cheese curds, in addition, a small proportion of the coagulant is carried over into the cheese. This residual coagulant remains proteolytically active in most aged cheeses and plays an important role in the development of texture and flavor by minimizing the cross linkage and by partial hydrolysis of milk proteins ${ }^{[15]}$.

The objective of this study was to study the effect of adjusting $\mathrm{PH}$ of the brine solution on meltability and stretch ability of white brained Nabulsi cheese.

Nabulsi cheese preservation and deterioration: Nabulsi cheese is classified as semi-hard cheese (moisture content 45-55\%).It is boiled in brine for the sake of preservation ${ }^{[10]}$ and is the major cheese consumed in Jordan and the West Bank ${ }^{[15]}$. White brined Nabulsi cheese is usually prepared from sheep milk and sometimes from goat milk ${ }^{[6]}$.
The keeping ability of Nabulsi cheese depends mainly on high salt concentration of storage medium (brine) and boiling of cheese before storage in cans ${ }^{[10]}$. The boiled cheese may develop bad flavor during storage in cans, slime formation, bitterness gassiness or hardening problem, in spite of high salt concentration of the brine. It was found that the cause of deterioration is halophytic bacteria that are able to grow at high salt concentration. All these defects can effect quality of cheese and cause severe deterioration in cheese ${ }^{[22]}$. Therefore, in a study to avoid high salts and microbial growth effect, reduced the PH by adding lactic acid. Decreasing the $\mathrm{PH}$ of cheese to 4 by the addition of lactic acid permitted the reduction of salt in brine and cheese to $10 \%$ concentration, this combination inhibited the growth of bacteria without negatively affecting texture and sensory quality of cheese.

Importance of Nabulsi cheese in the production of Arabic sweets: Desalting of Nabulsi cheese make it suitable for consuming at breakfast, as snack or as an ingredient in the preparation of local traditional dishes and sweets, especially Kunafa ${ }^{[6]}$. Kunafa (Kunafeh or Knafeh) is probably the most popular Arab sweets in many Arab Middle Eastern countries. Kunafa is made of a vermicelli like threads made of wheat batter formed on heated metal surfaces. The threads are mixed with ghee and spread over round aluminum baking pan covered with a desalted Nabulsi cheese layer, then covered with a further Kunafa threads layer and baked in both sides. The baked Kunafa is sweetened with a heavy sugar syrup flavored with rose essence. A second way of preparation is to grind the threads after mixing with ghee to fine granules, a layer of these granules, is spread over a baking plate, covered with desalted Nabulsi cheese and sprinkled with a light layer of the dough granules then baked and thoroughly on a special gas flame, then turned over a second plate, heated gently and sweetened with sugar syrup ${ }^{[29]}$.

One of the most important characteristic of the used cheese in Kunafa preparation is meltability and stretchability, the meltability is important to brand cheese to Kunafa crumbs to form a continuous layer facilitating turning over of Kunafa, whereas stretchability is favored by the consumer as in pizza ${ }^{[29]}$.

Methods of introducing meltability and stretchability in different cheese types: The original method of Nabulsi cheese processing does not include any steps or efforts to introduce meltability and stretchability, such characteristics when found in Nabulsi cheese are rather incidental. However, cheese 
factories that are specialized in production of cheese for Kunafa delay the salting step of the drained curd to permit the natural flora to act on the proteins and the $\mathrm{PH}$, whereas other factories may apply acidification of milk by citric acid along with coagulating enzyme, these method must be accompanied with flash heat treatment (quick boiling) of cheese instead of boiling for the usual time to avoid denaturation of the protein that arrest meltability and stretchability. This type of cheese may spoil quickly as a result of short heat treatment $^{[6]}$.

In contrast to Nabulsi cheese, many cheese types such as Mozzarella, Cheddar and Braided cheese includes conditions that lead to meltability and stretchability.

These conditions are as follows:

Mozzarella cheese represents a renneted, acid curd cheese in which lactic acid development is carefully controlled, exposure of the drained curd to warm temperature (about $54^{\circ} \mathrm{C}$ ) heating permits a mild acid ripening to $\mathrm{PH}$ 5.2-5.4. This critical $\mathrm{PH}$, along with warm temperature exposure gives a smooth stretching quality to the cheese due to conversion of dicalcium paracasein to monocalcium paracasein ${ }^{[22]}$.

This phenomenon seems to occurs in other cheeses like Cheddar. In fact, $35-96 \%$ of dicalcium paracasein of Cheddar curd is transformed to monocalcium paracesinate with increasing lactic acid that is produced from streptococci starter with a PH drop to 5.3. Also the aging process of this type of cheese for 4-12 months gives a good chance for different types of protease enzymes to affect cheese texture and make it stretchable and meltable ${ }^{[28]}$.

Braided cheese becomes stretchable as a result of curd heating before shaping. The curd is kept in boiling whey until it floats to the surface, then the curd which has become elastic in texture, is stretched and braided into the final shape ${ }^{[21]}$.

Effect of pH changes by direct acidification meltability and stretchability: During manufacturing of most cheese varieties the development of acidity is one of the basic operations during the manufacturing phase $^{[23]}$. Acidification affects several aspects of cheese manufacturing, taking into account that the effect varies between the indirect acidification (starter addition) and the direct acidification (acid addition). According to ${ }^{[7]}$, acidification has the following effects on:

- Curd strengthening which influences cheese yield

- The enzyme activity during coagulation and thus the amount required
- The $\mathrm{pH}$ which determines the extent of dissolution of colloidal calcium phosphate that influences the rheological properties of these cheese

- Gel syneresis which controls cheese moisture

Al-Ruqaie et al. ${ }^{[4]}$ found that Domiati cheese could be successfully made from buffalo's milk by the direct acidification method at $\mathrm{pH} 5.9$ using hydrochloric or lactic acid, but the cheese made with lactic acid was of superior quality as compared with the control cheese made from milk acidified with hydrochloric acid.

The effect of direct acidification on the composition of Ras cheese was studied by ${ }^{[9]}$. The cheese was made from buffalo's milk by direct acidification with hydrochloric acid at $\mathrm{pH} 5.8$ and lactic acid at $\mathrm{pH}$ 5.9. It was found that the acidification procedure saved more than $50 \%$ of the operation time as compared with cheese made following the traditional methods. However, the direct acidification technique had no significant effect on the yield, acidity, salt and total nitrogen content of the cheese, neither with the use of hydrochloric nor with lactic acid.

In another study ${ }^{[9]}$ found that direct acidification increased the protein breakdown in the resultant cheese (Ras Cheese) through out the ripening period, as indicated by the increased levels of soluble nitrogen, tyrosine and tryptophan.

Moreover, the acidity of cheese fat in direct acidification cheese was slightly higher than the control during ripening. No difference was observed in the quality of the cheese produced when using hydrochloric acid at pH 5.8 or lactic acid at 5.9.

Breene et $a .^{[2]}$ studied the effect of direct acidification in production of pizza cheese made from acidified milk with lactic, acetic or hydrochloric acid at 5.6. It was found that the optimum stretchability of mozzarella cheese is obtained at $\mathrm{pH}$ 5.2-5.4 for a biologically acidified curd or $\mathrm{pH} 5.6$ for chemically acidified curd.

Kindstedt et al. ${ }^{[13]}$ studied the effect of direct acidification on mozzarella cheese. The cheese was produced from acidified milk using phosphoric, acetic, hydrochloric and malic or citric acid at different $\mathrm{pH}$ values. The moisture content, mineral retention and rheological properties were affected significantly by the type of acid and $\mathrm{pH}$ at coagulation.

Queso Blanco is the most important white cheese of Latin America, traditionally produced through the addition of glacial acetic acid to milk and the application of heat without the use of rennet, However, lactic, phosphoric, citric and tartaric acid are also used in the manufacture of this cheese variety ${ }^{[25]}$. 
Robert et al. ${ }^{[21]}$ studied the effect of direct acidification of boiled cow's milk with hydrochloric acid at pH6.1 on the rate of clotting time. They found that the acidification of boiled milk reduces the clotting time and increases the syneresis rate.

Methods of measuring meltability and
stretchability:
Meltability test: Meltability refers to the tendency of shredded or diced cheese particles to form uniform continuous mass upon heating ${ }^{[14]}$. Melting characteristics of cheeses, such as Mozzarella, Cheddar and processed cheese are the prime factor in determining quality for particular product applications. Various methods are available to study the phenomenon of cheese meltability.

The Schreiber ${ }^{[1,28]}$ tests are most commonly used in the industry. These methods are based on measuring the changes in the diameter or height of a cylindrical cheese samples after heating it in an oven.

Olson and Price ${ }^{[17]}$ modified the Arnott test to measure the melting behavior of pasteurized process cheese. Muthukumarappan et al. ${ }^{[16]}$ proposed some modifications to the Schreiber test. They recommended heating the cheese plug in oven set at $90^{\circ} \mathrm{C}$ for $5 \mathrm{~min}$ on aluminum plate and measuring the area of spread of melted cheese as indicator of cheese meltability.

Many attempts have been made to measure meltability in specific, objective and physical terms but none have been entirely successful. Smith et al. ${ }^{[26]}$, determined the flow curve of Mozzarella cheese at several temperatures by a capillary viscosimeter, but slippage and strong viscoelastic effects played a dominate role, making it impossible to obtain meaningful rheological data.

Park et al ${ }^{[18]}$ studied melting quality of cheese with a Differential Scanning Calorimeter (DSC). However, the DSC data were not useful in predicting melting behavior of cheese. Dynamic rheological testing has many applications in food industry and has been used with cheese ${ }^{[19,27]}$. Correlated the dynamic rheological properties of Cheddar cheese up to $90^{\circ} \mathrm{C}$ with the meltability data from Arnott test. However, dynamic testing of cheese is hard to perform at high temperature as sample slippage may distort the results. A way to overcome the slip and viscoelastic effects while assessing the viscosity of cheese is to use squeezing flow rheometry. The Squeezing flow technique has been widely used to study cheese meltability ${ }^{[7]}$. Creep test is one of the fundamental measurements by measuring the strain or deformation as a function of time when constant, instantaneous stress is applied.
Stretchability Test: Stretchability is the tendency of melted cheese, upon pulling, to form fibrous strands that elongate without breaking ${ }^{[12]}$. Stretchability is also called stringiness ${ }^{[12]}$. The helical viscometer method ${ }^{[12]}$ provides a combined index of meltability and Stretchability. The test measures the torque on a rotating t-bar spindle as the spindle is raised through a sample of melted cheese.

The Apparent Viscosity (AV) which indicates Stretchability of mozzarella cheese is defined as the maximum resistance recorded during the spindle's pass through the column of melted cheese and is expressed in relative units of full scale response by the Brookfield viscometer. Although the test is empirical in nature, its application to the study commercial Mozzarella cheese has proven useful ${ }^{[12]}$.

\section{MATERIALS AND METHODS}

Experimental cheese samples: Freshly drawn, cows and sheep milk was obtained from one local farm in AlDhulail (Abu-Hamdan Farm). This milk was used as follows to produce white brined.

\section{Nabulsi cheese:}

- Raw cow milk (200 L)

- Raw sheep milk (200 L)

- For the production of Mashmouleh cheese a mixture of raw cow milk $(34 \%, 86 \mathrm{~L})$ and raw sheep milk $(66 \%, 123 \mathrm{~L})$ was used

- The traditional method for the production of this of cheese as described by ${ }^{[10]}$ was followed (Fig. 1) except the salting step which was carried out by in brine salting instead of dry salting

Local market samples: Four commercial whit brined Nabulsi cheese samples and three desalted Mashmouleh cheese type specially used for Kunafa preparation, were purchased from the local market from different locations, as shown in Table 1.

Testing methods:

Meltability test: The method used in measuring meltability of cheese was described by ${ }^{[1]}$. It is based on heating a standardized cylindrical cheese specimen under specified conditions (oven temperature and time), followed by measuring the specimens diameter.

\begin{tabular}{|c|c|c|c|}
\hline No. & Trade mark & Origin & Source of milk \\
\hline 1 & Danking & Germany & Pasteurized cows milk \\
\hline 2 & Bashkavan & Turkey & Pasteurized cows milk \\
\hline 3 & Nordex & Denmark & Pasteurized cows milk \\
\hline 4 & Hamoudoh & Jordan & Pasteurized cows milk \\
\hline
\end{tabular}




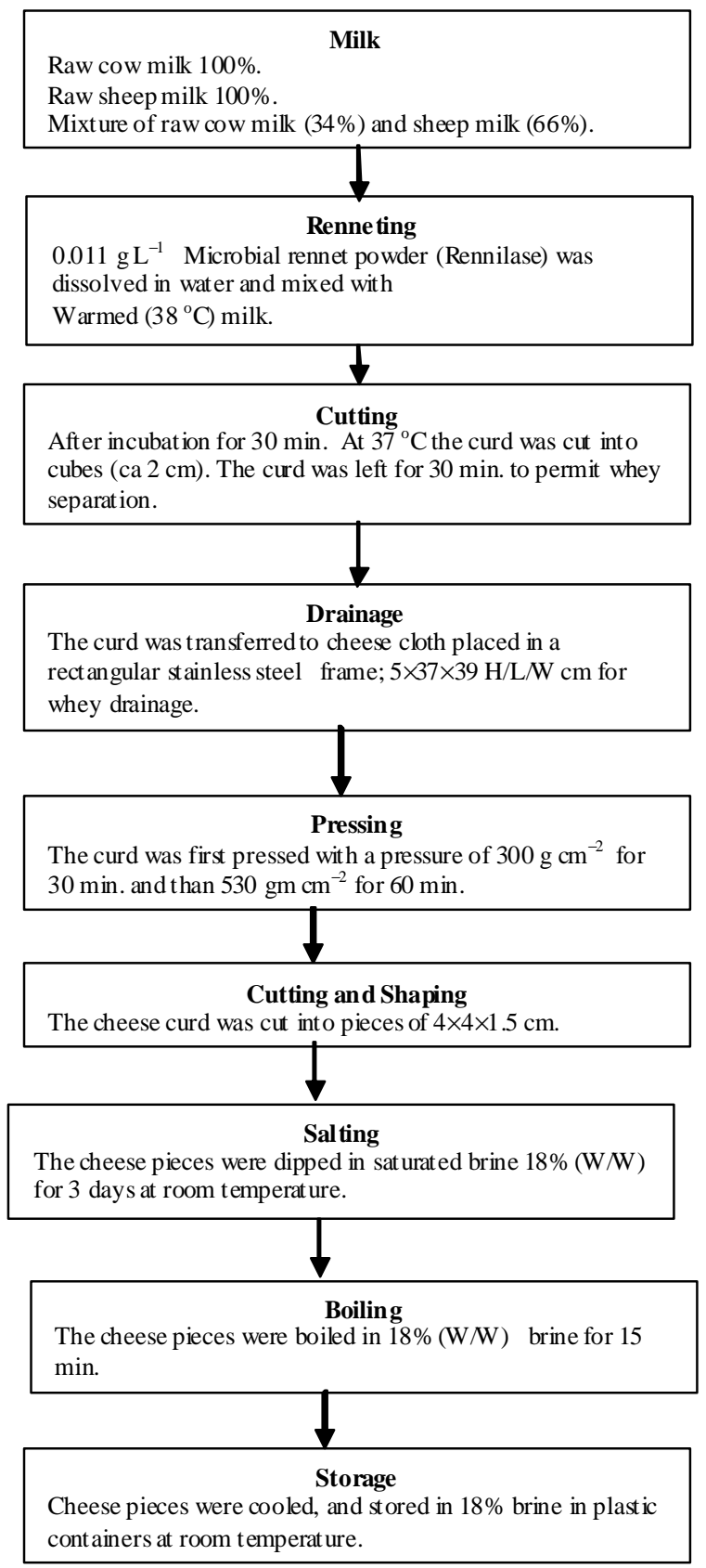

Fig. 1: Processing steps for the production of experimental white brined Nabulsi cheese

Cylindrical samples of $2 \mathrm{~cm}$ diameter and $1.5 \mathrm{~cm}$ height prepared as follows:

A test tube of $2 \mathrm{~cm}$ diameter is used as a probe to cut a specimen from a desalted cheese sample. The specimen is wrapped again and stored at $4^{\circ} \mathrm{C}$ until testing.
The cheese specimen is placed on a glass Petri dish. And heated at $100^{\circ} \mathrm{C}$ in a laboratory oven for $15 \mathrm{~min}$. At the end diameter of the specimen is measured.

\section{Stretchability test:}

Principle: A new apparatus was designed and constructed for measuring the stretchability of cheese ${ }^{[10]}$. It is based on heating a specified amount of cheese under specified conditions on a thermostatically controlled hot plate, followed by measuring the distance between the hot plate and mobile stretching plate before the cheese strands are torn off.

Measuring Procedure: A desalted $15 \mathrm{~g}$ cheese sample is manually crumbled using a spatula and spread evenly on the filter steady over the hot plate surface and preheated to $8^{\circ} \mathrm{C}(40 \mathrm{sec})$ the stretching plate is lowered by the pulley handle until settling on the heated sample and held for $5 \mathrm{sec}$. The stretching plate is then consciously and steadily lifted by the pulley handle until the stretched cheese strands are torn off. The distance between the two plates in $\mathrm{cm}$ is considered as a measure of stretchability.

Validation of stretchability test: Four different samples of Mozzarella cheese along with three types of desalted Mashmouleh cheese were measured for stretchability in order to validate the new method.

PH adjustments: Pre-experiments were carried out to determine the amount of citric acid needed to reach the desired $\mathrm{pH}$ a cheese amount was homogenized in the equivalent amount of the original storage brine solution using a kitchen blender, citric acid solution was gradually added under mixing until the desired $\mathrm{pH}$ was reached. The consumed citric acid amounts were recorded.

In the actual treatment, cheese cubes $(2 \times 2 \times 1.5 \mathrm{~cm})$ were taken with the equivalent amount of brine and the calculated (10\%) citric acid volumes were added,

After three weeks the equilibrium $\mathrm{pH}$ was reached Melt ability and stretchability of the different treatments were measured each week for duration of 4 weeks.

\section{RESULTS}

Stretchability test evaluation (method validation): A new instrument for measuring stretchability was designed and constructed.

The new instrument proved to be reliable for measuring stretchability. The cheese samples are 
indicative. However, a test of choice for measuring stretchability of cheese should measure the actual formation of strands during heating of the sample.

Mantling of both plates (hot plate and stretching plate) with filter steady used to facilitate adhesion of the molten sample on the surface that is a basic requirement for stretching. The filter studays are changed after each measurement that makes cleaning after each measurement easy. The maximum distance limit of this apparatus is $80 \mathrm{~cm}$, some of the samples reached this value and would exceed it.

Table 2 shows the results of stretchability measurements of four Mozzarella and three Mashmouleh cheese samples of different origins.

The values of the five runs of each sample indicate that there is no significant difference between them. This confirms the validity of the measuring method in term of high reproducibility.

Means with the same letter within the same row are not significant difference $(\mathrm{p}<0.05)$.

Effect of adjusting $\mathrm{pH}$ on meltability and stretchability of Nabulsi cheese.
Table 3 shows the effect of adjusting $\mathrm{pH}$ and storage time on meltability and stretchability of desalted white brined Nabulsi cheese made from cow milk.

It is obvious that $\mathrm{pH} 5.8$ and 5.4 are the most suitable $\mathrm{pH}$ values for implying meltability and stretchability to the cheese after the first week and throughout the four weeks of storage with significant differences at $(\mathrm{p} \leq 0.05)$ from the other treatments.

At $\mathrm{pH} 4.6$ meltability and stretchability were not existent, at the isoelectric point of casein, the cheese was, upon heating, mealy with no adhesiveness.

Means with the same letter within the same column are not significantly different.

The highest melt ability $(3 \mathrm{~cm})$ and stretch ability $(17.5 \mathrm{~cm})$ values were recorded at $5.8 \mathrm{pH}$ at four week of storage period. These values could be judged as acceptable and the method is practical. However, further investigation is needed to evaluate the effectiveness of other acids like lactic acid and phosphoric acid or in a mixture. It is worth notifying that acidification is also desirable to improve keeping ability of this type of cheese that originally lacks acidity.

Table 2: Stretchability values of different commercial Mozzarella and Mashmouleh * samples (methods validation)

\begin{tabular}{|c|c|c|c|c|c|c|c|c|c|c|}
\hline \multirow[b]{3}{*}{ No } & \multirow[b]{3}{*}{ Cheese type } & \multicolumn{6}{|c|}{ Stretchability $* *($ length in $\mathrm{cm})$} & \multirow[b]{3}{*}{ Mean } & \multirow{3}{*}{$\begin{array}{l}\text { Standard } \\
\text { deviation }\end{array}$} & \multirow{3}{*}{$\begin{array}{l}\text { Coefficient } \\
\text { of variation }\end{array}$} \\
\hline & & \multirow[b]{2}{*}{ Origin } & \multicolumn{5}{|c|}{ Runs } & & & \\
\hline & & & 1 & 2 & 3 & 4 & 5 & & & \\
\hline \multirow[t]{5}{*}{$\overline{1}$} & Mozzarella & Germany & & & $42 \mathrm{a}$ & $42 \mathrm{a}$ & & $41.2 \mathrm{c}$ & 0.84 & 2.03 \\
\hline & Danking & Turkey & $40 \mathrm{a}$ & $41 \mathrm{a}$ & $50 \mathrm{a}$ & $52 \mathrm{a}$ & $41 \mathrm{a}$ & $50.8 \mathrm{a}$ & 0.84 & 1.65 \\
\hline & Bashkavan & Denmark & $50 \mathrm{a}$ & $51 \mathrm{a}$ & $44 \mathrm{a}$ & $44 \mathrm{a}$ & $51 \mathrm{a}$ & $43.6 \mathrm{~b}$ & 0.54 & 1.24 \\
\hline & Nordex & Jordan & $44 a$ & $43 a$ & $40 \mathrm{a}$ & $42 \mathrm{a}$ & $43 a$ & $41.4 \mathrm{c}$ & 0.82 & 1.98 \\
\hline & Hamoudeh & Amman & $42 a$ & $41 \mathrm{a}$ & & & $42 \mathrm{a}$ & $50.2 \mathrm{a}$ & 0.45 & 0.89 \\
\hline \multirow[t]{5}{*}{2} & Desalted & Zarka & & & & $50 \mathrm{a}$ & $50 \mathrm{a}$ & $51.2 \mathrm{a}$ & 0.84 & 1.64 \\
\hline & Mashmouleh & Zarka & & & $50 \mathrm{a}$ & $52 \mathrm{a}$ & $51 \mathrm{a}$ & $51.2 \mathrm{a}$ & 0.45 & 0.88 \\
\hline & Sample no.1 & & $50 \mathrm{a}$ & $51 \mathrm{a}$ & $52 \mathrm{a}$ & $52 \mathrm{a}$ & $51 \mathrm{a}$ & & & \\
\hline & Sample no.2 & & $51 \mathrm{a}$ & $50 \mathrm{a}$ & $51 \mathrm{a}$ & & & & & \\
\hline & Sample no. 3 & & $51 \mathrm{a}$ & $51 \mathrm{a}$ & & & & & & \\
\hline
\end{tabular}

*: Desalted Mashmouleh: desalted white brined cheese purchased from sweet shops; **: Measurement using the new apparatus designed for the purpose of the study

Table 3: Effect of adjusting * $\mathrm{pH}$ of the brine and storage time on meltability and stretchability of Nabulsi cheese made form cow milk

\begin{tabular}{|c|c|c|c|c|c|c|c|c|c|}
\hline \multicolumn{10}{|c|}{ Storage time ( week) } \\
\hline \multirow{2}{*}{\multicolumn{2}{|c|}{$\begin{array}{l}\text { Sample PH of the } \\
\text { No. cheese }\end{array}$}} & \multicolumn{4}{|c|}{ Meltability $* *($ Diameter in $\mathrm{cm})$} & \multicolumn{4}{|c|}{ Stretchability $* * *($ Length in $\mathrm{cm})$} \\
\hline & & $1 \mathrm{w}$ & $2 \mathrm{w}$ & $3 w$ & $4 \mathrm{w}$ & $1 \mathrm{w}$ & $2 w$ & $3 w$ & $4 w$ \\
\hline$\overline{1}$ & Control (6.6) & $2.00_{\mathrm{d}}$ & $2.10_{c}$ & $2.20_{\mathrm{d}}$ & $2.20_{\mathrm{c}}$ & $3.50_{\mathrm{c}}$ & $5.50_{\mathrm{b}}$ & $6.50_{c}$ & $7.00_{c}$ \\
\hline 2 & 6.2 & $2.10_{\mathrm{c}}$ & $2.25_{\mathrm{c}}$ & $2.30_{\mathrm{c}}$ & $2.30_{\mathrm{b}}$ & $4.50_{\mathrm{a}, \mathrm{b}, \mathrm{c}}$ & $5.00_{\mathrm{b}}$ & $5.00_{c}$ & $6.00_{\mathrm{c}}$ \\
\hline 3 & 5.8 & $2.50_{\mathrm{a}}$ & $2.50_{\mathrm{a}, \mathrm{b}}$ & $2.75_{a}$ & $2.00_{\mathrm{a}}$ & $6.50 \mathrm{a}$ & $8.50_{\mathrm{a}}$ & $16.00_{\mathrm{a}}$ & $17.50_{\mathrm{a}}$ \\
\hline 4 & 5.4 & $2.45_{\mathrm{a}}$ & $2.65_{\mathrm{a}}$ & $2.75_{\mathrm{a}}$ & $2.85_{\mathrm{b}}$ & $5.00_{\mathrm{b}}$ & $8.00_{\mathrm{a}}$ & $11.00_{\mathrm{b}}$ & $13.00_{\mathrm{b}}$ \\
\hline 5 & 5.0 & 2.25 & $2.45_{\mathrm{b}}$ & $2.5_{\mathrm{b}}$ & $2.50_{\mathrm{c}}$ & $4.00_{\mathrm{b}, \mathrm{c}}$ & $5.50_{\mathrm{b}}$ & $5.50_{\mathrm{c}}$ & $5.00_{\mathrm{c}}$ \\
\hline 6 & 4.6 & None $_{\mathrm{e}}$ & None $_{\mathrm{d}}$ & None $_{\mathrm{e}}$ & None $_{f}$ & None $_{d}$ & None $_{c}$ & None $_{d}$ & None $_{d}$ \\
\hline
\end{tabular}

*: PH Adjusting by adding (10\%) Citric acid considering the buffering capacity of the cheese at equilibrium; **: Meltability measurement was performed on the cheese after desalting, using ${ }^{[1]}$; **: Stretchability measurement was performed on the cheese after desalting, using the new apparatus designed for the purpose of the study 


\section{DISCUSSION}

Values as high as $40 \mathrm{~cm}$ are considered as excellent stretchability, thus measurements of stretchability higher than $80 \mathrm{~cm}$ is not of practical value

However, there are significant differences between the values of stretchability of the various Mozzarella cheese samples but not Mashmouleh samples. The instrument is simple and demonstrates the actual stretchability unlike the helical viscometer which measures the resistance to the impeller of the viscosimeter as an indicator of stretchability.

The $\mathrm{pH}$ adjustment was done in original brine of cheese samples using citric acid. Citric acid is chemically classified as a good cheater of the cheese which was experimentally predetermined through titration of a brine/cheese slurry.

The acidification process of brined cheese by citric acid allows the conversion of dicalcium Para casein to monocalcium Para casein as shown below:

Calcium Casinate+Rennin $\rightarrow$ Dicalcium procrastinate (precipitation or curd)

Dicalcium procrastinate+Citric acid $\rightarrow$ Monocalcium paracesinate (smooth and stretchable)

The $\mathrm{pH}$ values for optimum stretchability was found to be 5.2-5.4 for Mozzarella cheese ${ }^{[15]}$, that conform to the lower value found for Nabulsi cheese.

\section{CONCLUSION}

- Adjusting the $\mathrm{pH}$ of Nabulsi cheese by the addition of citric acid induced a low but considerable level of stretch ability and melt ability after 3-4 weeks storage

- Further investigation are needed to evaluate the effect of using acids other than citric acid like lactic acid and phosphoric acid to adjust $\mathrm{pH}$ of the cheese on is it meltability and stretchability

\section{REFERNCES}

1. Hofi, A.A., E.H. Youssef, M.A. Ghoneim and G.A. Tawab, 1970. Ripening changes in cephalotyre "RAS" cheese manufactured from raw and pasteurized milk with special reference to flavor. J. Dairy Sci., 53: 1207-1211. http://jds.fass.org/cgi/content/abstract/53/9/1207.

2. Trujillo, A.J., B. Guamis and C. Carretero, 2000. A procedure for the manufacture of goat milk cheese with controlled-microflora by means of high hydrostatic pressure. 69: 73-79. DOI: 10.1016/S0308-8146(99)00242-3.
3. Aly, S. and E.A. Galal, 2002. Effect of milk pretreatment on the keeping quality of Domiati cheese. Pak. J. Nutr., 1: 132-136. DOI: 10.1128/AEM.01667-06.

4. Al-Ruqaie, I.M., H.M. El-Nakhal and A.N. Wahdan, 1987. Improvement in the quality of $t$ he dried ferment milk product. Ogytt. J. Dairy Res., 54: 429-435.

5. Arnott, K., R. Morries, H.A. and W.B. Combs, 1957. Effect of certain chemical factors on the melting quality of process cheese. J. Dairy Sci., 40:

957-963. http://jds.fass.org/cgi/content/abstract/40/8/957.

6. Basson, P., 1981. Women and Traditional food technologies: Changes in rural Jordan. Preparation of food at home. Ecol. Food Nutr., 11: 17-23.

7. Campanella, O.H., L.M. Popplewell, J.R. Rosenan and M. Peleg, 1987. Elongational viscosity measurement of melting American process cheese. J. Food Sci., 52: 1251-1279. http://www3.interscience.wiley.com/journal/11947 0245/abstract?CRETRY $=1 \&$ SRETRY $=0$.

8. El-Erian, A.F., A.H. Farag and S.M. El-Gendy, 1975. Chemical studies on mish cheese. Agric. Res. R., 53: 173-185.

9. Hassan, A.N., 2007. Structure development in cheese. Proceeding of the 10th Egyptian Dairy Science and Technology Conference, Nov. 19-21, Cairo, Egypt.

10. Humeid, H.A., H.A. Tukan, S.K. and M.I. Yamani, 1990. In bag steaming of white brined cheese as a method of preservation. Michwissenchaft, 45: 513-516. http://www.fao.org/agris/search/display.do?f=./1991/v17 17/DE91V0008.xml;DE91V0008.

11. Kindstedt, P.S., 1993. Effect of manufacturing factors, composition and proteolysis on the functional characteristics of mozzarella cheese. Critical Rev. Food Sci. Nutrit., 33: 167-173. http://www.fao.org/agris/search/display.do?f=./199 6/v2227/US9615812.xml;US9615812.

12. Kindstedt, P.S., J.K. Rippe and C.M. Duther, 1989. Application of helical viscometry to study commercial mozzarella cheese melting properties. Dairy $\quad$ Sci., 72: 3123-3128. http://jds.fass.org/cgi/content/abstract/72/12/3123.

13. Kindstedt, P.S., J.J. Yun, D.M. Barbano and K.L. Larsoe, 1995. Mozzarella cheese: Impact of coagulant concentration on chemical composition proteolysis and functional properties. J. Dairy Sci., 78: 2591-2597. http://jds.fass.org/cgi/content/abstract/78/12/2591.

14. Kindstet, P.S. and L.J. Kiely, 1992. Revised protocol for analysis of melting properties of mozzarella chess by heliecal visscometry. J. Dairy Sci., 75: 676-683. 
15. Messer., J.W., H.M. Behirey and L.O. Leudecke, 1985. Standard Methods for Examination of Dairy Products. 15th Edn., American Public Health Association, Washington, DC., ISBN 08-75531326, pp: 412.

16. Muthukumarappan, K., Y.C. Wang and K. Gunase, 1999. Short Communication: Modified schreiber test for evaluation of mozzarella cheese melt ability. J. Dairy Sci., 82: 1068-1071. http://jds.fass.org/cgi/content/abstract/82/6/1068.

17. Olson, N.F. and W.V. Price, 1958. A melting test for pashurized process cheese spreads. J. Dairy Sci., 41: 999-1000.

18. Park, J., J.R. Rosenan and Peleg, 1984. Comparison of four procedures of cheese meltability evaluation. J. Food Sci., 56: 1158-1170. http://www3.interscience.wiley.com/journal/11952 4698/abstract.

19. Pederson, C.S., 1979. Microbiology of Food Fermentations. 2nd Edn., The AVI Publishing Company Westport, USA., ISBN: 08-705-52775, pp: 384.

20. Upreti, P. and L.E. Metzger, 2006. Influence of calcium and phosphorus, lactose and salt-tomoisture ratio on cheddar cheese quality: Manufacture and composition. J. Dairy Sci., 89: 420-428. http://jds.fass.org/cgi/content/abstract/89/2/420.

21. Jenness, R., N.P. Wong, E.H. Marth and M. Keeney, 1995. Fundamentals of Dairy Chemistry. 3rd Edn., Van Nostrand Reinhold, New York.

22. Sawaya, W.N., J.P. Salji, M. Ayazand J.K. Khalil, 1984. The chemical composition and nutritive value of madeer. Ecol. Food. Nutr., 67: 1655-1659. http://jds.fass.org/cgi/content/abstract/67/8/1655.
23. Scott, R., 1986. Cheese Making Practice. 2nd Edn., Elsevier Applied Science Publishers, London and New York.

24. Govindasamy-Lucey, S., T. Lin, J.J. Jaeggi, M.E. Johnson and J.A. Lucey, 2006. Influence of condensed sweet cream buttermilk on the manufacture, yield and functionality of pizza cheese. J. Dairy Sci., 89: 454-467. http://jds.fass.org/cgi/content/abstract/89/2/454.

25. Siapantas, L., 1981. Flavor Profile of Queso Blanco. In: The Quality of Foods and Beverages: Chemistry and Technology, Charalambous, G. and Inglett (Eds.). Acad Press, New York, pp: 326-340.

26. Smith, C.E., J.R. Rosenan and M. Peleg, 1980. Evaluation of the flowability of melted mozzarella cheese by capillary rheometry. J. Food Sci., 45:

1142-1145. http://www3.interscience.wiley.com/journal/11958 5348/abstract.

27. Ustunol, Z.K. and J. Steffe, 1994. Arnott test corelate with dynamic rheological properties for determining cheddar cheese meltability. J. Food Sci., 59: 960-971.

28. Van Veen, A.G. and K.H. Steinkraus, 1970. Nutritive value and whole someness of fermented foods. J. Agric. Food Chem., 18: 576-578. http://pubs.acs.org/doi/abs/10.1021/jf60170a038.

29. Yammani, M.I., J.K. Tukan and S.J. Abu-Tayeh, 1997. Microbiologicl quality of kunafa and the development of a Hazard Analysis Critical Control Point (HACCP) plan for its production. Dairy Food Environ. Sanitat., 17: 638-643. 